\title{
The Effects of Traffic Calming Measures on Pedestrian and Motorist Behavior
}

REPORT NO. FHWA-RD-00-104 August 2001
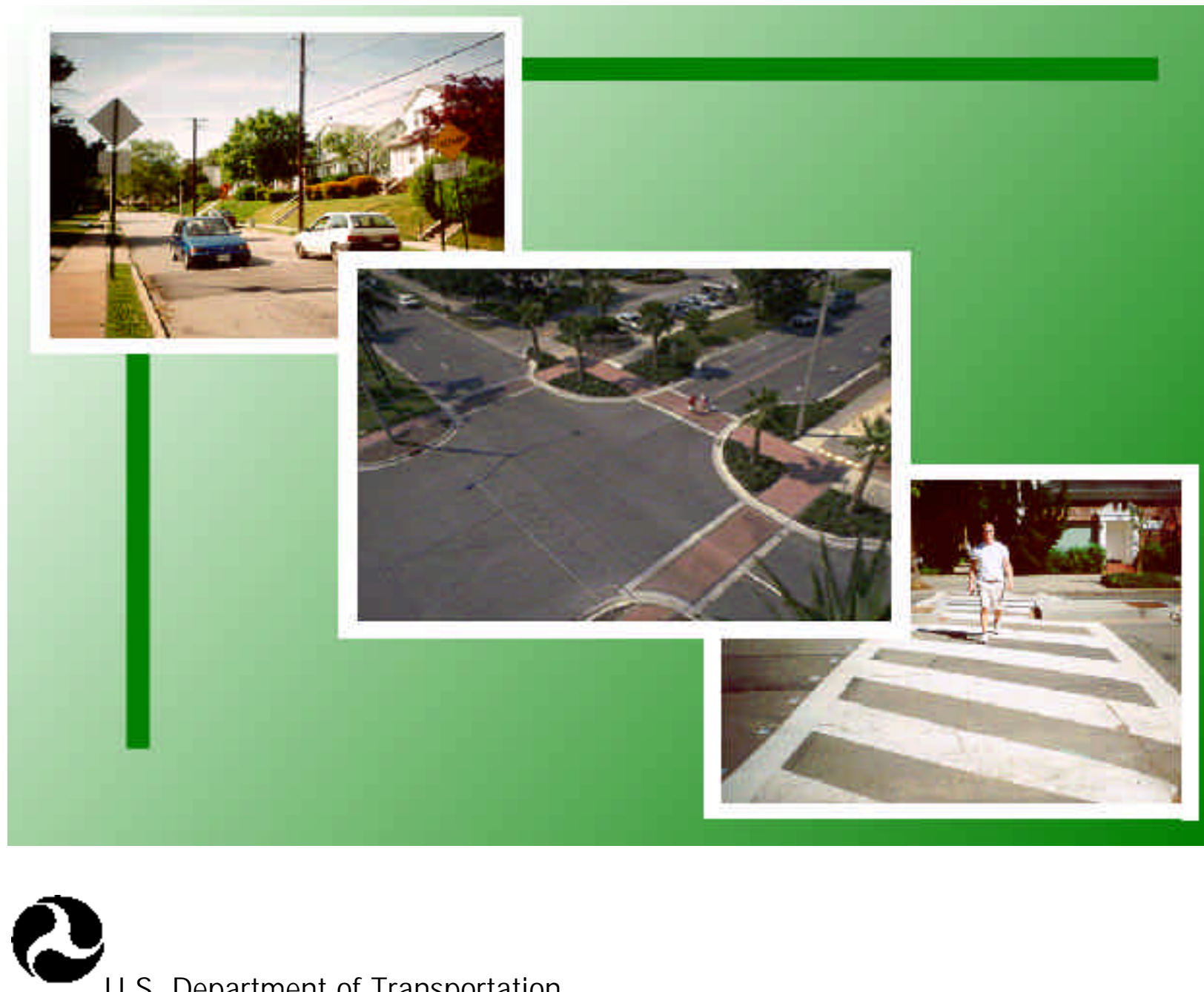

U.S. Department of Transportation

Federal Highway Administration

Research, Development, and Technology

Turner-Fairbank Highway Research Center

6300 Georgetown Pike

McLean, VA 22101-2296

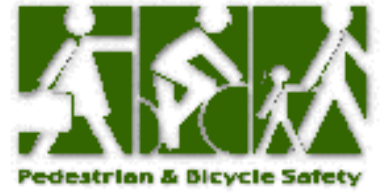




\section{FOREWORD}

The FHWA's Pedestrian and Bicycle Safety Research Program's overall goal is to increase pedestrian and bicycle safety and mobility. Traffic calming has been used on residential streets to help reduce vehicle speeds. In addition to reducing vehicle speeds, traffic calming treatments may also benefit pedestrians by shortening crossing distances and enhancing motorist and pedestrian visibility.

This reports documents an evaluation of the effects of selected traffic calming treatments on both pedestrian and motorist behavior. This study was part of a larger Federal Highway Administration research study investigating the effectiveness of engineering treatments on pedestrian and bicycle safety. It is hoped that readers also will review the reports documenting the results of the other pedestrian and bicycle safety studies.

The results of this research will be useful to transportation engineers, planners, and safety professionals who are involved in improving pedestrian safety and mobility.

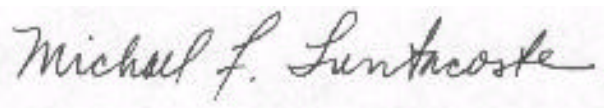

Michael F. Trentacoste

Director, Office of Safety Research and Development

\section{NOTICE}

This document is disseminated under the sponsorship of the Department of Transportation in the interest of information exchange. The United States Government assumes no liability for its content of use thereof. This report does not constitute a standard, specification or regulation.

The United States Government does not endorse products or manufactures. Trade and manufactures' names appear in this report only because they are considered essential to the object of the document. 


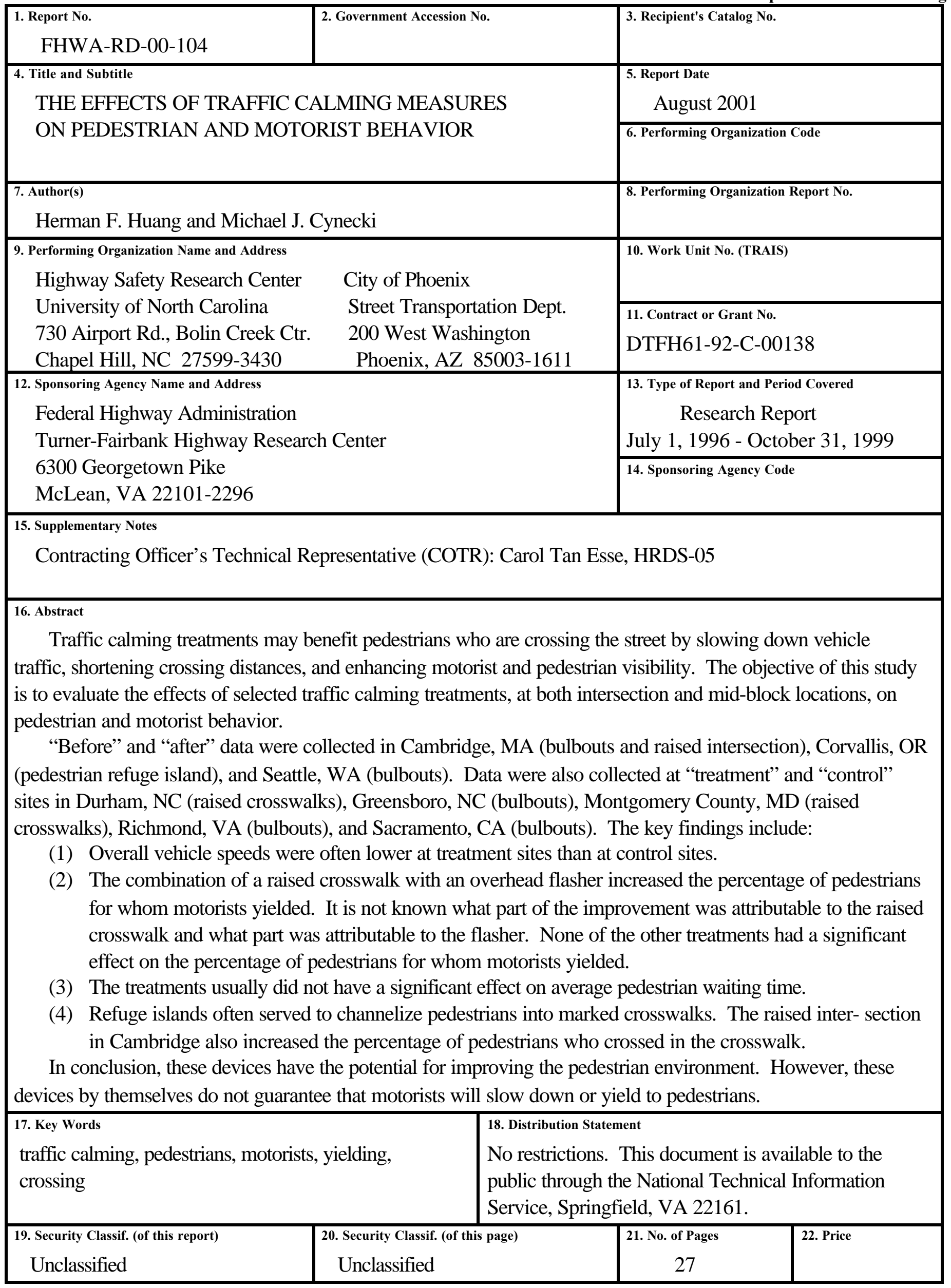


TABLE OF CONTENTS

\section{Page}

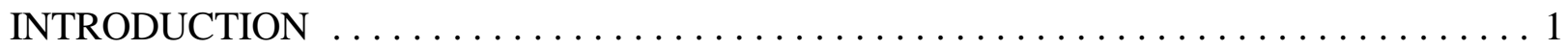

Past Research on the Effects of Speed Humps $\ldots \ldots \ldots \ldots \ldots \ldots \ldots \ldots \ldots \ldots \ldots \ldots \ldots \ldots \ldots \ldots$

Previous Studies on the Effects of Bulbouts and Street Narrowing $\ldots \ldots \ldots \ldots \ldots \ldots$

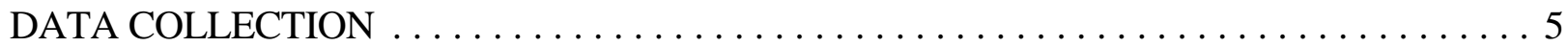

BULBOUTS - CAMBRIDGE AND SEATTLE $\ldots \ldots \ldots \ldots \ldots \ldots \ldots \ldots \ldots \ldots \ldots \ldots \ldots$

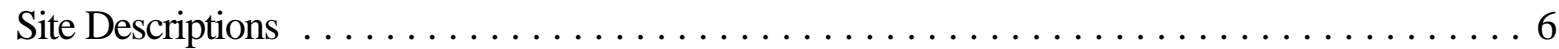

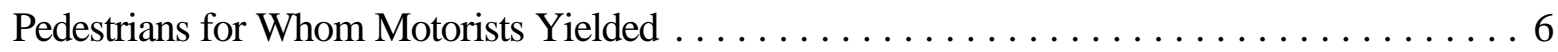

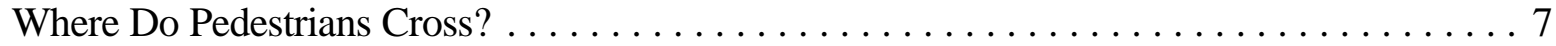

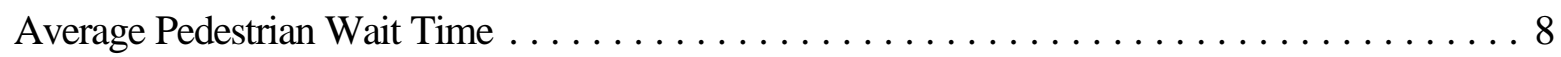

BULBOUTS - GREENSBORO AND RICHMOND $\ldots \ldots \ldots \ldots \ldots \ldots \ldots \ldots \ldots$

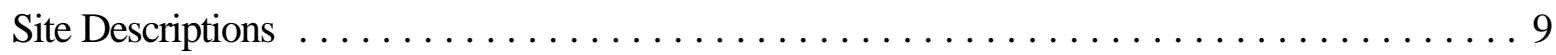

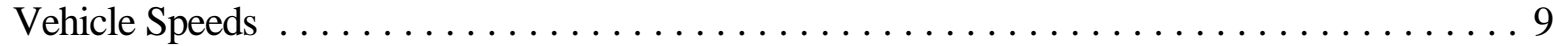

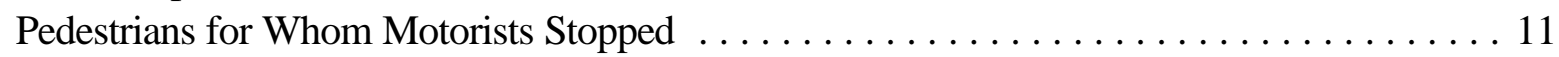

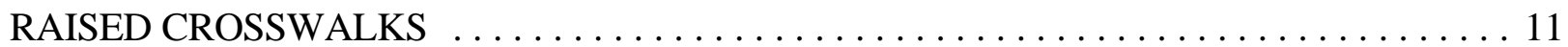

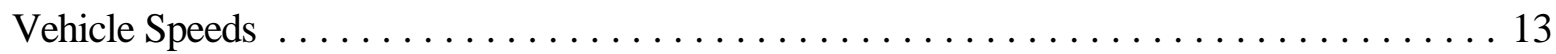

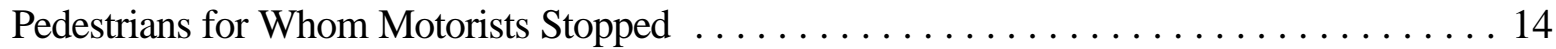

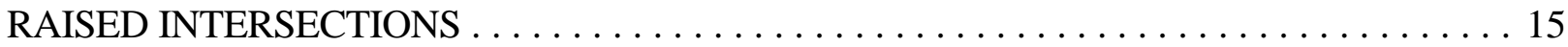

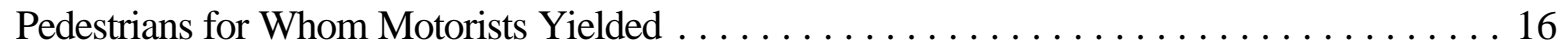

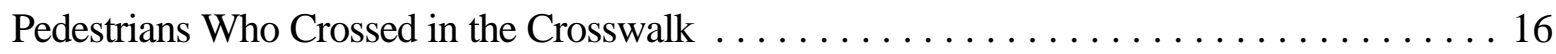

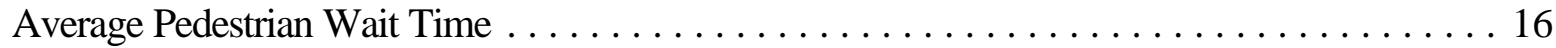

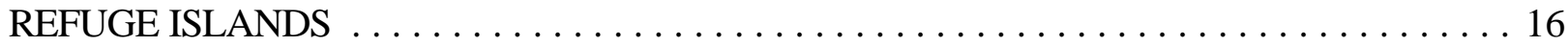

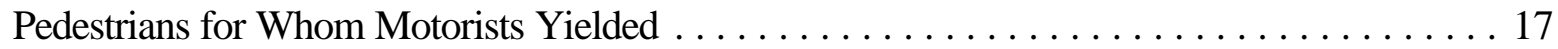

Where Do Pedestrians Cross? . . . . . . . . . . . . . . . . . . . . . . . 18

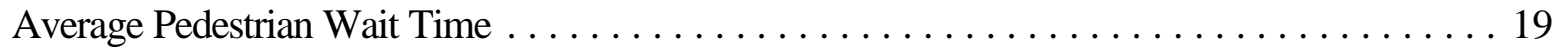

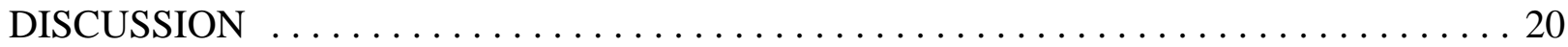

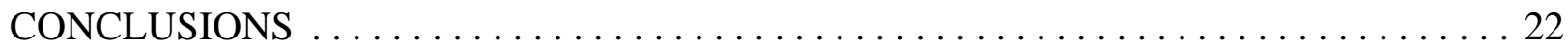

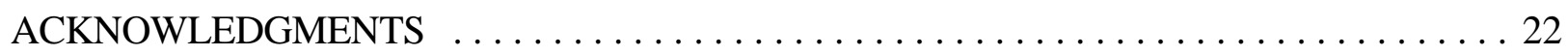

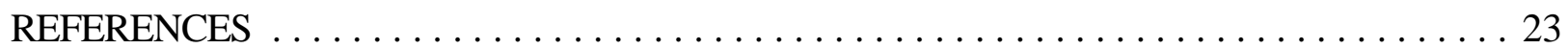




\section{LIST OF FIGURES}

Page

Figure 1. Two vehicles slow down as they pass over a speed hump $\ldots \ldots \ldots \ldots \ldots \ldots \ldots$

Figure 2. Pedestrians using a raised crosswalk $\ldots \ldots \ldots \ldots \ldots \ldots \ldots \ldots \ldots \ldots \ldots \ldots$

Figure 3. Bulbouts shorten crossing distances for pedestrians, improve sight distances,

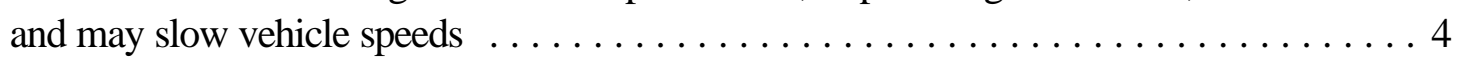

Figure 4. A motorist yielding to pedestrians, Alki at $59^{\text {th }}$, Seattle $\ldots \ldots \ldots \ldots \ldots \ldots \ldots$

Figure 5. Bulbout and textured crosswalk, Greensboro, North Carolina . . . . . . . . . . 10

Figure 6. Raised crosswalk and overhead flasher, Towerview Drive, Durham,

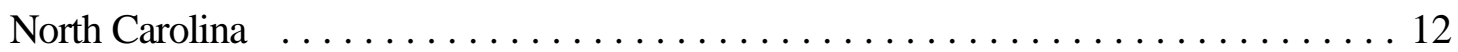

Figure 7. Raised crosswalk, Bel Pre Road at Merton Road, Montgomery Country,

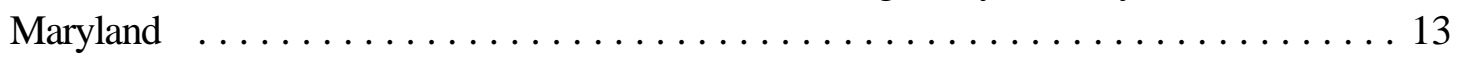

Figure 8. Raised intersection, Berkshire Street and Marcella Street, Cambridge,

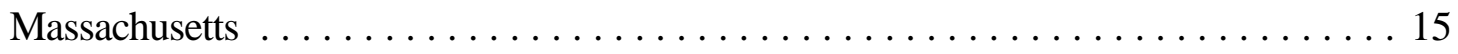

Figure 9. Refuge island, Circle Boulevard, Corvallis, Oregon $\ldots \ldots \ldots \ldots \ldots \ldots$

Figure 10. Pedestrian in crosswalk with refuge island, Sacramento, California $\ldots \ldots \ldots \ldots$ 


\section{LIST OF TABLES}

Page

Table 1. Percentage of Pedestrians for Whom Motorists Yielded, Before and After

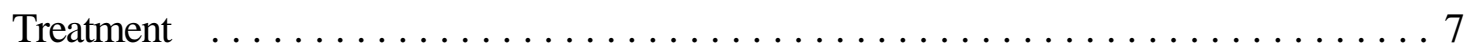

Table 2. Percentage of Pedestrians Who Crossed in the Crosswalk, Before and After

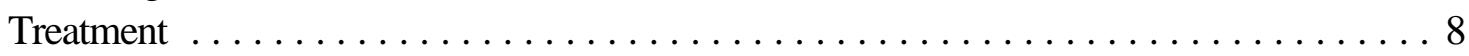

Table 3. Average Pedestrian Wait Time, Before and After Treatment $\ldots \ldots \ldots \ldots \ldots \ldots$

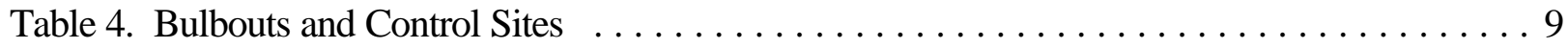

Table 5. Comparison of Vehicle Speeds at the Treatment and Control Sites $\ldots \ldots \ldots \ldots \ldots$

Table 6. Pedestrians for Whom Motorists Stopped to Let Them Cross $\ldots \ldots \ldots \ldots \ldots \ldots$

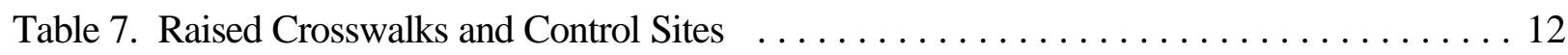

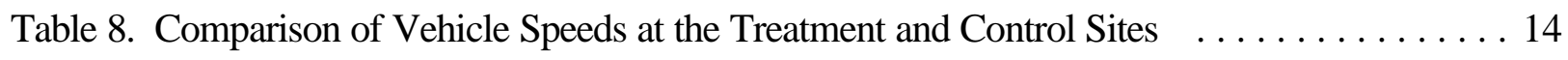

Table 9. Pedestrians for Whom Motorists Stopped to Let Them Cross $\ldots \ldots \ldots \ldots \ldots$

Table 10. Percentage of Pedestrians for Whom Motorists Yielded, Before and

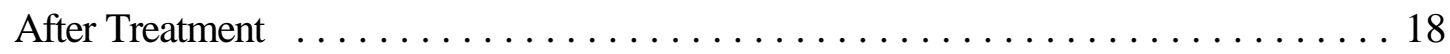

Table 11. Percentage of Pedestrians Who Crossed in the Crosswalk, Before and

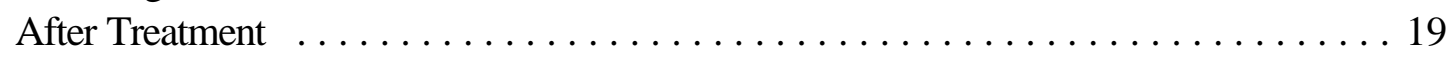

Table 12. Average Pedestrian Wait Time, Before and After Treatments ............... 20

Table 13. Summary of Traffic Calming Devices by Site and MOE $\ldots \ldots \ldots \ldots \ldots \ldots \ldots$ 


\section{INTRODUCTION}

Continued growth and decentralization throughout the United States have increased the number of cars on streets and highways. High traffic volumes and speeds, especially on residential streets, reduce the quality of life for residents because of concerns about safety, noise, and pollution. As a result, many neighborhood residents and local officials have expressed interest in undertaking traffic calming as a means of decreasing the cars' dominance.

Traffic calming encompasses a series of physical treatments that are meant to lower vehicle speeds and volumes by creating the visual impression that certain streets are not intended for highspeed or cut-through traffic. Thus, traffic calming can improve safety for pedestrians and reduce noise and pollution levels. Examples of these measures include bulbouts, speed humps, chicanes, and traffic circles.

This paper summarizes past research on speed humps, bulbouts, and roadway narrowing. Findings from a new evaluation of bulbouts, raised crosswalks and intersections, refuge islands, and speed humps in eight communities are also reported. Whereas earlier studies usually focused on vehicle speeds and volumes, this study looked at motorist yielding and pedestrian crossing behavior, in addition to vehicle speeds. The research reported in this paper is part of a national-level research effort to evaluate the operational and safety effects of pedestrian treatments, such as traffic calming, crosswalks, sidewalks, automated pedestrian detection, and illuminated push buttons.

\section{Past Research on the Effects of Speed Humps}

Also known as road humps, undulations, or "sleeping policemen," the purpose of speed humps is to promote the smooth flow of traffic at slow speeds of about 32 to $40 \mathrm{~km} / \mathrm{h}$ (20 to $25 \mathrm{mi} / \mathrm{h}$ ). The speed hump is an elongated hump with a circular-arc cross-section (round-top) or flat-top, rising to a height of $76 \mathrm{~mm}$ (3 in) above the normal pavement surface and having a length of $3.7 \mathrm{~m}$ to $6.7 \mathrm{~m}$ (12 ft to $22 \mathrm{ft}$ ) in the direction of vehicular travel (Figure 1). Speed humps usually extend the full width of the road, excluding the gutter to allow for drainage (1).

Raised crosswalks are flat-top speed humps with crosswalk markings painted on the top (Figure 2). Raised crosswalks elevate pedestrians above the surface of the roadway and can make them more visible to motorists. Raised crosswalks cause motorists to slow at the most critical location, where pedestrians cross. They are generally designed to keep pedestrians at one level so that there is no need for curb ramps. Drainage is accommodated by pipes along the gutter or other design features. 


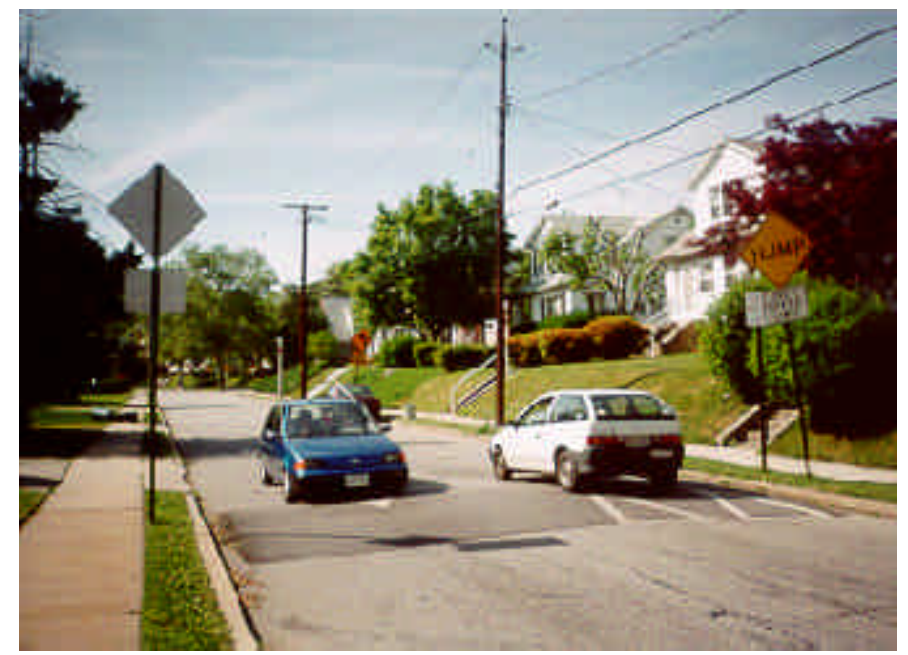

Figure 1. Two vehicles slow down as they pass over a speed hump.

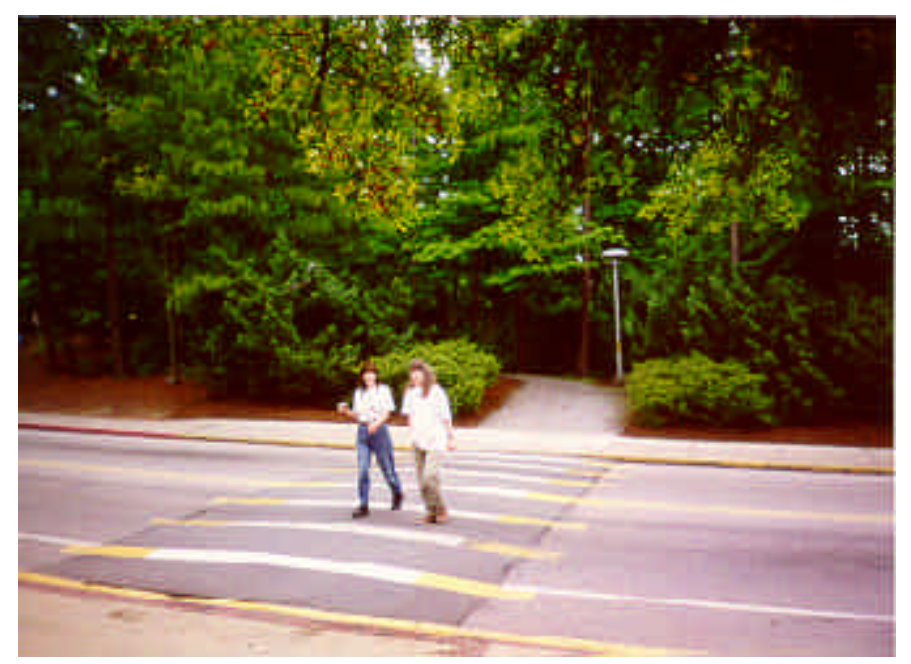

Figure 2. Pedestrians using a raised crosswalk.

Speed humps have been evaluated in many cities. The following paragraphs summarize some of those studies.

In Omaha, Nebraska, before and after data at 10 speed hump locations found a significant reduction (at the 5 percent significance level) in the 85 th percentile speeds. Data collected from 19 locations showed that the number of accidents involving personal injury decreased. However, residents complained about the speeding that still existed, increased noise levels, and vehicle damage. City officials were concerned about emergency vehicle access and response time, potential liability, and the need to monitor signs and pavement markings for the speed humps ( $\underline{2})$. 
In Bellevue, Washington, 16 speed humps were installed in 5 residential neighborhoods. The 85 th percentile speeds declined from 58 to $63 \mathrm{~km} / \mathrm{h}$ ( 36 to $39 \mathrm{mi} / \mathrm{h}$ ) prior to installation to 39 to 43 $\mathrm{km} / \mathrm{h}$ (24 to $27 \mathrm{mi} / \mathrm{h}$ ) after installation. Traffic volumes fell when alternate routes existed. Most residents felt that the humps were effective and favored their continued use (3).

Speed humps in Montgomery County, Maryland, typically reduced 85th percentile speeds by 6 to $11 \mathrm{~km} / \mathrm{h}$ (4 to $7 \mathrm{mi} / \mathrm{h})$. The installation of the humps reduced accident frequency. The humps did not have a consistent effect on traffic volumes, though (4). The speed-reducing effect was stronger in adjacent Howard County, Maryland. There, the use of speed humps on a number of streets lowered the $85^{\text {th }}$ percentile speeds by $14 \mathrm{~km} / \mathrm{h}$ to $37 \mathrm{~km} / \mathrm{h}(9 \mathrm{mi} / \mathrm{h}$ to $23 \mathrm{mi} / \mathrm{h})(\underline{5})$.

Five speed humps were built along a 0.8-km (0.5-mi) stretch of Grey Rock Road in Agoura Hills, California. Instead of the customary 76-mm (3-in) height, these humps were $70 \mathrm{~mm}$ ( $2.75 \mathrm{in})$ high. The 85 th percentile traffic speeds fell by 10 to $15 \mathrm{~km} / \mathrm{h}$ ( 6 to $9 \mathrm{mi} / \mathrm{h}$ ) after the humps were installed. Traffic volumes remained constant and motorists did not divert to other residential streets ( $\underline{6})$.

The speed humps placed in Westlake Village, California, were $67 \mathrm{~mm}$ (2.625 in) high. The humps reduced the 85th percentile speeds by 15 to $23 \mathrm{~km} / \mathrm{h}$ ( 9 to $14 \mathrm{mi} / \mathrm{h}$ ) to 39 to $47 \mathrm{~km} / \mathrm{h}$ ( 24 to 29 $\mathrm{mi} / \mathrm{h})$. Several demonstration projects in Los Angeles used the 67-mm (2.625-in ) high speed humps, with results similar to those in Agoura Hills and Westlake Village (ㅁ).

In three Australian cities, Corio and Croydon in Victoria and Stirling in Western Australia, the 85th percentile speeds at speed humps dropped by half or more after installation. Mid-hump speeds fell by about one-fourth to one-third. Daily traffic volumes fell by one-fourth to roughly one-half ( $\underline{7} ; \underline{8}$; 9).

\section{Previous Studies on the Effects of Bulbouts and Street Narrowing}

The purpose of a bulbout (also known as a choker, curb bulb, neckdown, nub, or gateway) is to reduce the width of vehicle travel way at an intersection or a mid-block pedestrian crossing. Bulbouts shorten the street crossing distance for pedestrians, may slow vehicle speeds, and provide pedestrians and motorists with an improved view of one another, thereby reducing the risk of a motor vehicle-pedestrian collision (Figure 3).

Anne Arundel County, Maryland, has used a combination of medians and bulbouts near intersections. The medians narrow the traveled way and provide a sheltered storage area, while the bulbouts force drivers to make a lateral deflection as they enter the narrowed area. Medians with lateral deflection reduced the 85 th percentile speeds by $3 \mathrm{~km} / \mathrm{h}$ to $8 \mathrm{~km} / \mathrm{h}$ ( 2 to $5 \mathrm{mi} / \mathrm{h})(\underline{5})$. 


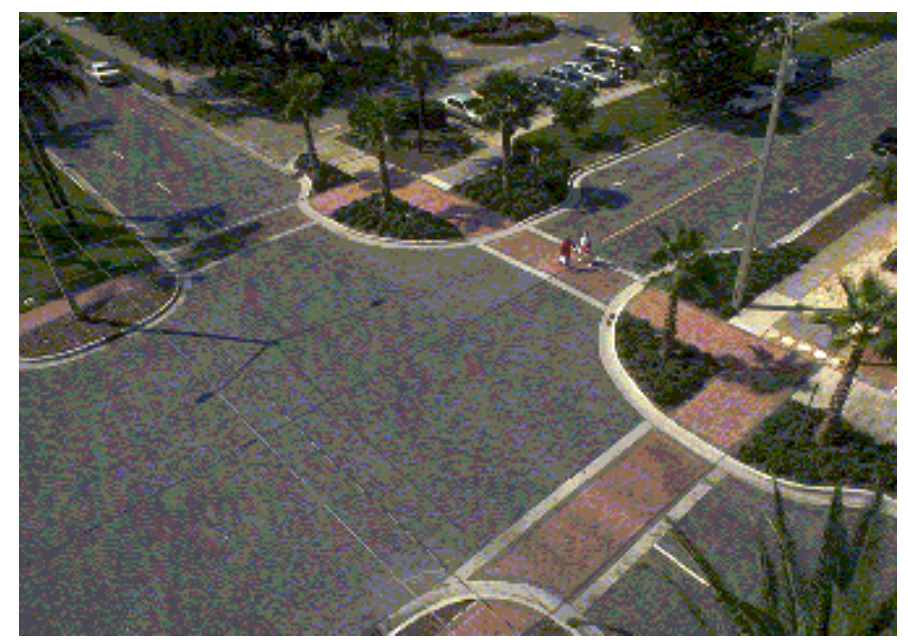

Figure 3. Bulbouts shorten crossing distances for pedestrians, improve sight distances, and may slow vehicle speeds.

In Ontario, Canada, Macbeth (스) reported speed reductions on five raised and narrowed intersections and seven mid-block bulbouts, in conjunction with lowering the speed limit to $30 \mathrm{~km} / \mathrm{h}$. The proportion of motorists who exceeded $30 \mathrm{~km} / \mathrm{h}$ was 86 percent before the devices were built, but only 20 percent afterwards.

The Dutch towns of Oosterhout and De Meern have both installed street narrowing variations. The Oosterhout project consisted of installing two bulbouts so as to require motorists to deviate from a straight path. Both the 85th percentile vehicle speed and the degree of pedestrian-motor vehicle conflict fell after the bulbouts were installed. In De Meern, two bulbouts were placed opposite one another to narrow the width of the traveled way. A significant reduction in the 85th percentile vehicle speed was observed (11).

In two Australian cities, Keilor (Queensland) and Eltham (Victoria), bulbouts had little effect on reducing vehicle speeds. However, in Concord, New South Wales, a comparison of a street with both bulbouts and marked parking lanes versus an untreated street showed that the crash rate on the treated street was only one-third that of the untreated street. It was not stated how many of these crashes involved pedestrians, nor how the streets compared prior to treatment ( $\underline{9})$.

The Australian "wombat" crossing usually consists of a raised crosswalk and bulbouts. It is designed to slow motorists, shorten pedestrian exposure to motor vehicles, and increase pedestrian visibility to motorists. Wombat crossings have generally reduced 85 th percentile vehicle speeds by about 40 percent (ㅁ). 


\section{DATA COLLECTION}

Four types of traffic calming devices were evaluated in this study: (1) bulbouts, (2) raised crosswalks, (3) raised intersections, and (4) refuge islands. Both before-and-after and treatment-andcontrol study designs were used. The findings are presented in the following sections, along with information about the study locations and study designs.

Before and after data were collected using a video camera, prior to and following the installation of each treatment. The video camera was set up on the sidewalk, approximately $61 \mathrm{~m}$ (200 ft) upstream from the crossing location. The camera faced in the same direction as traffic on that half of the roadway. This position allowed the camera to record, on videotape, pedestrians in the crosswalk and in the queuing areas on either side of the roadway. The camera also recorded whether approaching motorists stopped or slowed down for pedestrians. Videotaping was done mostly on weekdays, during daylight hours, and under dry conditions (when it was neither raining nor snowing). The length of videotaping at each location ranged from 2 to $8 \mathrm{~h}$.

For the treatment-and-control design, each treatment site was matched with a control site that did not have a traffic calming device in place but was otherwise similar. Data were collected through real-time observations and the use of speed-measuring devices (more details in the following sections). Data were collected on weekdays, during daylight hours, and under dry conditions. The data collection periods ranged from about $40 \mathrm{~min}$ to $4 \mathrm{~h}$.

Each traffic calming device was evaluated according to two or three measures of effectiveness (MOEs):

1. Vehicle speeds

2. Pedestrians for whom motorists stopped or yielded

3. Crossing in the crosswalk

4. Average wait time

With regard to pedestrians for whom motorists stopped or yielded, the pedestrian was the unit of analysis. Only pedestrians who crossed when motorists were approaching are included in the analysis. For example, if a total of 100 pedestrians crossed when vehicles were approaching, and motorists yielded to 50 pedestrians, then the percentage of pedestrians for whom motorists yielded is equal to 50 percent. It does not matter whether the 50 pedestrians crossed as one large group (with one motorist yielding), several smaller groups (with several motorists yielding), or one by one (with 50 motorists yielding).

Wait time refers to the time that a pedestrian waits, after arriving at the curb, before he or she starts to cross the roadway. When no vehicles are present, pedestrians can cross immediately after they arrive at the curb. When vehicles are present, pedestrians typically either wait for a gap that they 
perceive to be adequate, or until an approaching motorist stops or slows down, before they start crossing.

The results for the MOEs are described in more detail below. The reader is advised that sample sizes vary even at the same location, because of the way that the MOEs were defined. For some observations, individual data items were not recorded, and these observations were not included in the analysis.

\section{BULBOUTS - CAMBRIDGE AND SEATTLE}

A before-and-after study approach was used to evaluate four bulbouts in two cities.

1. Berkshire Street at Marney Street, Cambridge, MA

2. Berkshire Street at York Street, Cambridge, MA

3. Alki Avenue SW at $59^{\text {th }}$ Avenue SW, Seattle, WA

4. $\quad$ East Pike Street at $11^{\text {th }}$ Avenue, Seattle, WA

\section{Site Descriptions}

Both bulbout locations in Cambridge are in residential neighborhoods. Berkshire Street is one-way northbound. Marney Street is one block north of York Street and meets Berkshire from the east, at a T-intersection. There is a city park on the west side of Berkshire. Traffic and pedestrian volumes were low during the times that data collection took place.

In Seattle, Alki Avenue SW is an arterial along the waterfront. There is considerable pedestrian activity on sunny days during the warmer months. The neighborhood is largely residential, with some shops and restaurants. The intersection of East Pike Street at $11^{\text {th }}$ Avenue is just east of downtown Seattle and is predominantly retail.

\section{Pedestrians for Whom Motorists Yielded}

By constricting the roadway, bulbouts are intended to slow vehicles down and increase the likelihood that motorists will see pedestrians sooner than they would otherwise. Therefore, it was hypothesized that bulbouts would increase the number of pedestrians for whom motorists yielded. In other words, more pedestrians would have the benefit of motorists yielding to them (Figure 4).

The chi-square statistic was used to compare the percentages of pedestrians for whom motorists yielded in the before and after periods (Table 1). The bulbouts in Seattle did not have a statistically significant effect on the percentage of pedestrians for whom motorists yielded, not even at the 0.10 level. The bulbouts in Cambridge had small sample sizes. 


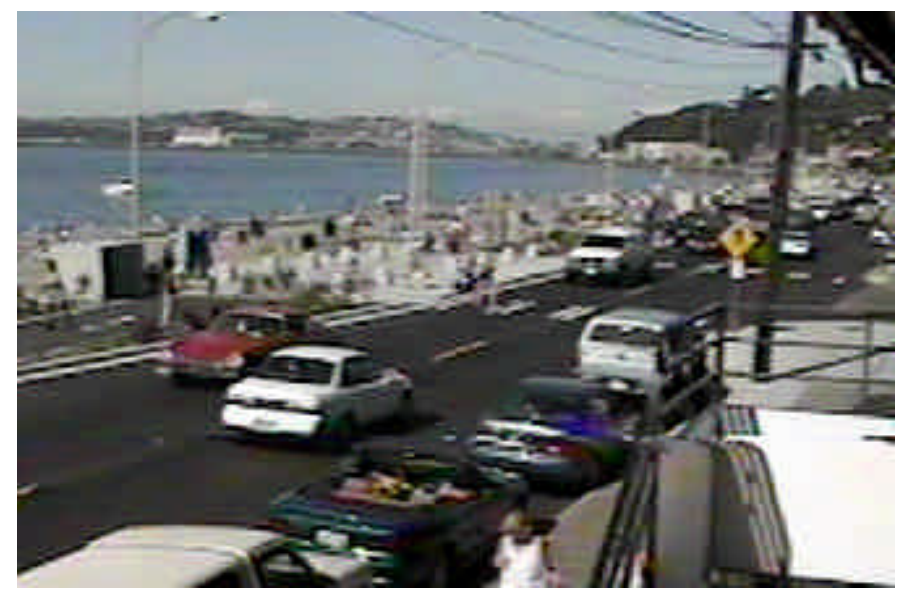

Figure 4. A motorist yielding to pedestrians, Alki at $59^{\text {th }}$, Seattle.

Table 1. Percentage of Pedestrians for Whom Motorists Yielded, Before and After Treatment.

\begin{tabular}{|l|c|l|l|c|}
\hline \multicolumn{1}{|c|}{ LOCATION } & TREATMENT & BEFORE & AFTER & $\begin{array}{c}\text { SIGNIFICANC } \\
\text { E }\end{array}$ \\
\hline Cambridge, MA & $\begin{array}{c}\text { Bulbouts } \\
2 \text { locations }\end{array}$ & $20.0 \%(5)^{*}$ & $66.7 \%(6)$ & $\mathrm{S}$ \\
\hline Seattle, WA & $\begin{array}{c}\text { Bulbouts } \\
2 \text { locations }\end{array}$ & $57.9 \%(342)$ & $52.2 \% \quad(471)$ & $\mathrm{N}$ \\
\hline
\end{tabular}

ABBREVIATIONS

* Sample sizes in parentheses.

$\mathrm{N}$ Not significant.

S Small sample size.

\section{Where Do Pedestrians Cross?}

All of the traffic calming locations that were evaluated already had marked crosswalks in the "before" period. It was thought that bulbouts would motivate pedestrians to cross in the crosswalk (who otherwise might not have done so), so that they can benefit from the shorter crossing distances.

The chi-square statistic was used to compare the percentages of pedestrians who crossed in the crosswalk in the before and after periods. As Table 2 shows, the effects of the Cambridge bulbouts were in the desired direction but were not statistically significant, not even at the 0.10 level. The results for the bulbouts in Seattle were statistically significant, but in the undesired direction-more 
pedestrians crossed in the crosswalk before the bulbouts were installed than after they were installed.

Table 2. Percentage of Pedestrians Who Crossed in the Crosswalk, Before and After Treatment.

\begin{tabular}{|l|c|c|c|c|}
\hline \multicolumn{1}{|c|}{ LOCATION } & TREATMENT & BEFORE & AFTER & SIGNIFICANCE \\
\hline Cambridge, MA & $\begin{array}{c}\text { Bulbouts } \\
2 \text { locations }\end{array}$ & $66.7 \% \quad(60)^{*}$ & $67.2 \% \quad(64)$ & $\mathrm{N}$ \\
\hline Seattle, WA & $\begin{array}{c}\text { Bulbouts } \\
2 \text { locations }\end{array}$ & $93.7 \% \quad(824)$ & $74.1 \% \quad(939)$ & $\mathrm{X}$ \\
\hline
\end{tabular}

ABBREVIATIONS

* Sample sizes in parentheses.

$\mathrm{X}$ Significant, but in the wrong direction.

$\mathrm{N}$ Not significant.

\section{Average Pedestrian Wait Time}

Bulbouts may slow vehicle speeds, thus increasing the number of adequate gaps and also increasing the likelihood that an approaching motorist will yield to a pedestrian. Therefore, it was expected that bulbouts would shorten the time that pedestrians must wait to cross the street. In this study, wait times were recorded for all pedestrians who crossed the street, regardless of whether motor vehicles were approaching.

The $t$ test for difference in means was used to compare average pedestrian wait times in the before and after periods (Table 3). The effect of the bulbouts in Seattle was statistically significant but in the undesired direction, i.e., the wait times at the bulbouts were longer in the after period than in the before period. The average wait time at the bulbouts in Cambridge was $0.16 \mathrm{~s}(\mathrm{~N}=85)$ in the before period and $0.11 \mathrm{~s}(\mathrm{~N}=99)$ in the after period. According to the $t$ test for difference in means, this change was not statistically significant. Because traffic volumes were very light, the majority of pedestrians crossed without having to wait for a gap in traffic, so the average wait times were very short.

Table 3. Average Pedestrian Wait Time, Before and After Treatment.

\begin{tabular}{|l|c|c|c|c|}
\hline \multicolumn{1}{|c|}{ LOCATION } & TREATMENT & BEFORE & AFTER & SIGNIFICANCE \\
\hline Cambridge, MA & $\begin{array}{c}\text { Bulbouts } \\
2 \text { locations }\end{array}$ & $\begin{array}{c}0.16 \mathrm{~s} \\
\mathrm{~N}=85\end{array}$ & $\begin{array}{c}0.11 \mathrm{~s} \\
\mathrm{~N}=99\end{array}$ & $\mathrm{~N}$ \\
\hline Seattle, WA & $\begin{array}{c}\text { Bulbouts } \\
\text { 2 locations }\end{array}$ & $\begin{array}{c}1.19 \mathrm{~s} \\
\mathrm{~N}=1086\end{array}$ & $\begin{array}{c}1.76 \mathrm{~s} \\
\mathrm{~N}=1233\end{array}$ & $\mathrm{X}$ \\
\hline
\end{tabular}

ABBREVIATIONS

$\mathrm{X}$ Significant, but in the undesired direction.

$\mathrm{N}$ Not significant. 


\section{BULBOUTS - GREENSBORO AND RICHMOND}

A treatment-and-control study approach was used to evaluate four additional bulbouts (Table 4).

Table 4. Bulbouts and Control Sites.

\begin{tabular}{|l|l|}
\hline \multicolumn{1}{|c|}{ TREATMENT SITE } & \multicolumn{1}{c|}{ CONTROL SITE } \\
\hline $\begin{array}{l}\text { Elm Street, between Friendly Avenue and } \\
\text { Summit Avenue, Greensboro, NC }\end{array}$ & $\begin{array}{l}\text { Elm Street, between Market Street and } \\
\text { Friendly Avenue, Greensboro, NC }\end{array}$ \\
\hline $\begin{array}{l}\text { Elm Street, between Washington Street and } \\
\text { February One Place, Greensboro, NC }\end{array}$ & $\begin{array}{l}\text { Elm Street at Martin Luther King Jr. Drive, } \\
\text { south leg, Greensboro, NC }\end{array}$ \\
\hline $\begin{array}{l}\text { Ellwood Avenue at Auburn Avenue, Richmond, } \\
\text { VA }\end{array}$ & $\begin{array}{l}\text { West Main Street at Rowland Street, } \\
\text { Richmond, VA }\end{array}$ \\
\hline $\begin{array}{l}\text { Ellwood Avenue at Dooley Avenue, Richmond, } \\
\text { VA }\end{array}$ & Cary Street at Stafford Street, Richmond, VA \\
\hline
\end{tabular}

\section{Site Descriptions}

Elm Street in Greensboro is the main north-south downtown arterial. Both bulbouts and the control site between Market Street and Friendly Avenue are downtown. The control site at Martin Luther King Jr. Drive is on the southern edge of downtown. Elm Street is generally two-way, with one lane in each direction. There is usually parking on both sides. The crosswalks are made of textured pavement. Elm Street is lined with shops, offices, and several vacant buildings (Figure 5).

In Richmond, both bulbouts and their control sites were on two-lane, one-way streets in residential neighborhoods.

\section{Vehicle Speeds}

It was hypothesized that bulbouts would reduce vehicle speeds.

In Greensboro, automated traffic counters were used to measure the speeds of all vehicles, in both directions, at the crossing and about $30 \mathrm{~m}$ (100 ft) upstream from the crossing. Speeds were measured for about 8,900 vehicles at the bulbouts and 5,300 vehicles at the control sites. 


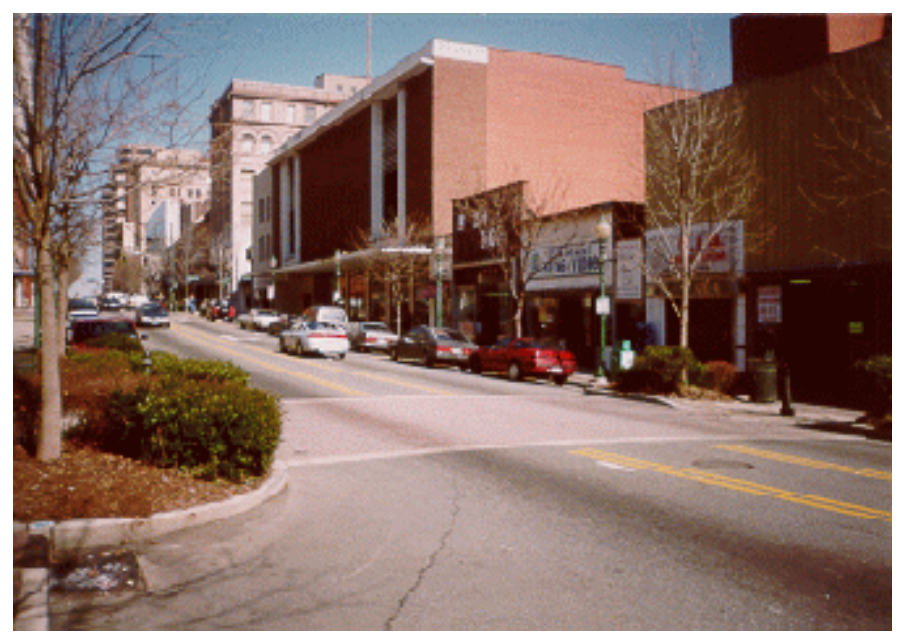

Figure 5. Bulbout and textured crosswalk, Greensboro, North Carolina.

A laser speed measurement gun was used in Richmond to measure the speeds of vehicles, in one

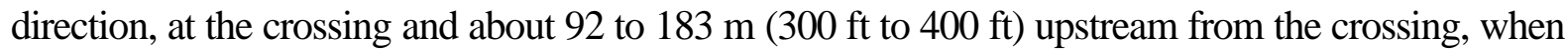
the staged pedestrian was present at the crossing. Speeds were measured for a total of 132 vehicles at the bulbouts and 132 vehicles at the control sites.

The 50th percentile speeds were calculated at all study sites (Table 5). The 50th percentile speeds in Greensboro were $1.8 \mathrm{~km} / \mathrm{h}(1.1 \mathrm{mi} / \mathrm{h})$ lower than at their corresponding control sites. This is consistent with the hypothesis. However, the difference may or may not be of practical significance.

Table 5. Comparison of Vehicle Speeds at the Treatment and Control Sites.

\begin{tabular}{|c|c|c|c|}
\hline $\begin{array}{c}\text { CITY AND } \\
\text { TREATMENT }\end{array}$ & $\begin{array}{c}\text { 50TH } \\
\text { PERCENTILE } \\
\text { SPEED } \\
\text { TREATMENT SITE }\end{array}$ & \begin{tabular}{|} 
50TH PERCENTILE \\
SPEED \\
CONTROL SITE
\end{tabular} & $\begin{array}{l}\text { DIFFERENCE IN } \\
\text { SPEEDS }\end{array}$ \\
\hline $\begin{array}{l}\text { Greensboro, NC } \\
2 \text { Bulbouts }\end{array}$ & $\begin{array}{l}26.4 \mathrm{~km} / \mathrm{h} \\
(16.4 \mathrm{mi} / \mathrm{h})\end{array}$ & $\begin{array}{r}28.2 \mathrm{~km} / \mathrm{h} \\
(17.5 \mathrm{mi} / \mathrm{h})\end{array}$ & $\begin{array}{l}1.8 \mathrm{~km} / \mathrm{h}(1.1 \mathrm{mi} / \mathrm{h}) \\
\text { lower at treatment site } \\
\text { SIGNIFICANT }^{1}\end{array}$ \\
\hline $\begin{array}{l}\text { Richmond, VA } 2 \\
2 \text { Bulbouts }\end{array}$ & $\begin{array}{l}53.1 \mathrm{~km} / \mathrm{h} \\
(33.0 \mathrm{mi} / \mathrm{h})\end{array}$ & $\begin{array}{l}49.9 \mathrm{~km} / \mathrm{h} \\
(31.0 \mathrm{mi} / \mathrm{h})\end{array}$ & $\begin{array}{l}3.2 \mathrm{~km} / \mathrm{h}(2.0 \mathrm{mi} / \mathrm{h}) \\
\text { higher at treatment site } \\
\text { SIGNIFICANT- } \\
\text { Undesired direction }\end{array}$ \\
\hline
\end{tabular}

Significant at the 0.05 level or better, using a two-tailed test.

2 Vehicle speeds in Montgomery County and Richmond were measured only when the staged pedestrian was present. 
In Richmond, the 50th percentile speeds were $3.2 \mathrm{~km} / \mathrm{h}(2.0 \mathrm{mi} / \mathrm{h})$ higher at the treatment site than at the corresponding control site (Table 5). This is contrary to what was hypothesized. It is not clear why the bulbout sites had higher speeds than the control sites.

\title{
Pedestrians for Whom Motorists Stopped
}

For this MOE, data were collected using a staged pedestrian. Because of low pedestrian activity in both Greensboro and Richmond, it was necessary to stage pedestrian crossings, using a two-person data collection team. The staged pedestrian was a researcher who moved into a staging position when a vehicle was 92 to $183 \mathrm{~m} \mathrm{(300} \mathrm{to} 600 \mathrm{ft}$ ) upstream from the crosswalk. In the staging position, the researcher stood at or near the curb and looked at oncoming traffic as if he / she were getting ready to cross the roadway. The second member of the team observed whether motorists slowed down when they saw the staged pedestrian, and whether they stopped to allow the staged pedestrian to cross. The staged pedestrian was male in Greensboro and female in Richmond.

Motorists stopped for fewer than 10 percent of the staged pedestrians in both Greensboro and Richmond. The differences between the treatment and control sites were not statistically significant, not even at the 0.10 level.

Table 6. Pedestrians for Whom Motorists Stopped to Let Them Cross.

\begin{tabular}{|c|c|c|c|}
\hline SITE AND TREATMENT & $\begin{array}{l}\text { TREATMEN } \\
\text { T SITE }\end{array}$ & $\begin{array}{l}\text { CONTROL } \\
\text { SITE }\end{array}$ & $\begin{array}{l}\text { SIGNIFICANC } \\
\text { E }\end{array}$ \\
\hline $\begin{array}{l}\text { Greensboro, NC } \\
\text { Bulbouts ( } 2 \text { locations) }\end{array}$ & $5.2 \% \quad(211)^{*}$ & $7.6 \% \quad(185)$ & $\mathrm{N}$ \\
\hline $\begin{array}{l}\text { Richmond, VA } \\
\text { Bulbouts (2 locations) }\end{array}$ & $0.0 \% \quad(66)$ & $0.0 \% \quad(66)$ & $\mathrm{N}$ \\
\hline
\end{tabular}

NOTE: Staged pedestrians were used in Greensboro and Richmond.

\author{
ABBREVIATIONS \\ * Sample sizes in parentheses. \\ N Not significant.
}




\section{RAISED CROSSWALKS}

Three raised crosswalks, each matched with a control site, were evaluated.

Table 7. Raised Crosswalks and Control Sites.

\begin{tabular}{|l|l|}
\hline \multicolumn{1}{|c|}{ TREATMENT SITE } & \multicolumn{1}{c|}{ CONTROL SITE } \\
\hline Research Drive, Durham, NC & Research Drive, Durham, NC \\
\hline $\begin{array}{l}\text { Towerview Drive, Durham, NC (This location } \\
\text { also has a continuous overhead flasher.) }\end{array}$ & Towerview Drive, Durham, NC \\
\hline $\begin{array}{l}\text { Bel Pre Road at Merton Road, Montgomery } \\
\text { County, MD }\end{array}$ & $\begin{array}{l}\text { Bel Pre Road at Merton Road, Montgomery } \\
\text { County, MD }\end{array}$ \\
\hline
\end{tabular}

Research Drive and Towerview Drive are both on the campus of Duke University in Durham, NC. Both are two-way streets, with one lane of traffic in each direction. Towerview has a parking

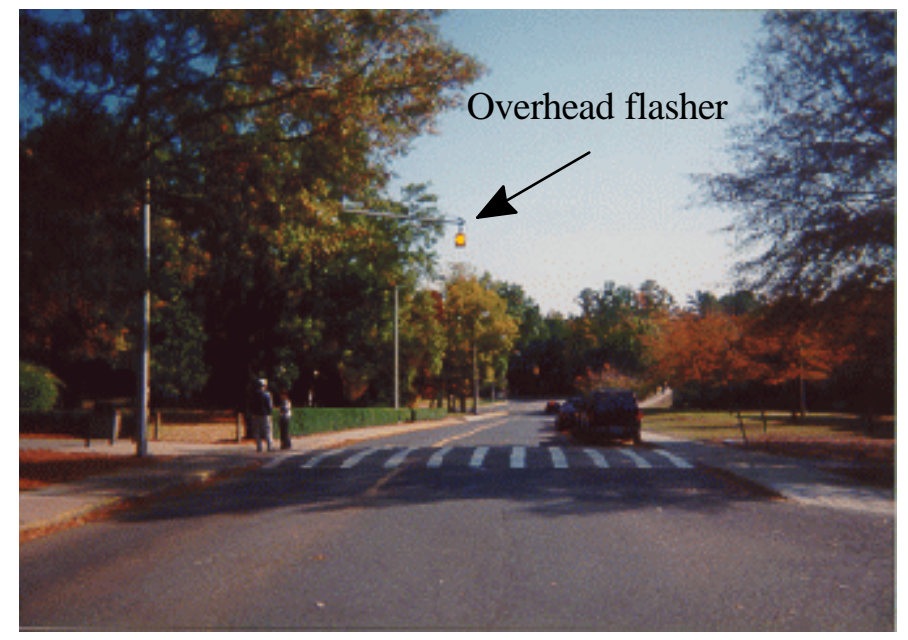

Figure 6. Raised crosswalk and overhead flasher, Towerview Drive, Durham, North Carolina.

lane in the eastbound direction. Traffic speeds were higher on Research Drive than on Towerview. This may be partly attributable to straighter alignment and longer sight distance on Research Drive. The location on Towerview Drive has both a raised crosswalk and a continuously operating overhead flasher (Figure 6). The corresponding control site has neither a raised crosswalk nor an overhead flasher, but it has a painted ladder crosswalk. 


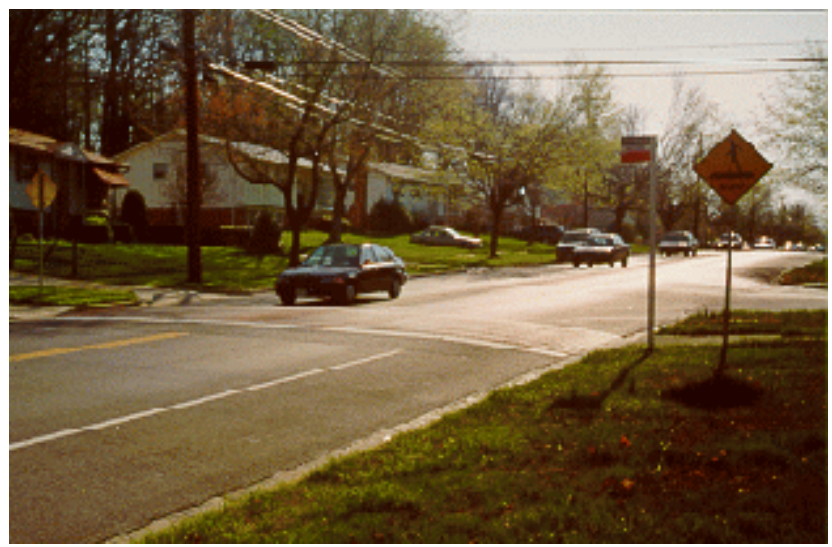

Figure 7. Raised crosswalk, Bel Pre Road at Merton Road, Montgomery County, Maryland.

Bel Pre Road at Merton Road is in a residential area just outside of Rockville, MD. Bel Pre is a northwest-southeast collector, with one lane of traffic in each direction and parking lanes on both sides. Merton Road is a local street that approaches from the southwest and forms a T-intersection with Bel Pre Road. The raised crosswalk is on the northwest leg of the intersection, and the control site is on the southeast leg of the same intersection (Figure 7).

\section{Vehicle Speeds}

Raised crosswalks are intended to slow vehicles down by forcing drivers to go up, across the crosswalk, and then back down again. The effect on vehicles is similar to that of a speed hump. It was hypothesized that raised crosswalks would lower vehicle speeds.

At the two raised crosswalks in Durham, automated traffic counters were used to measure the speeds of all vehicles, in both directions, at the crossing and about $30 \mathrm{~m}(100 \mathrm{ft})$ upstream from the crossing. The sample sizes at each site ranged from about 1,800 to 2,600 .

A laser speed measurement gun was used in Montgomery County to measure the speeds of vehicles, in one direction, at the crossing. The sample sizes were 42 vehicles at the raised crosswalk and 38 vehicles at the control site.

The 50th percentile speeds were calculated at all study sites. For both study sites in Durham, the 50th percentile speed was lower at the treatment site than at the control site, by 6.5 to $19.3 \mathrm{~km} / \mathrm{h}$ (4.0 to $12.4 \mathrm{mi} / \mathrm{h}$ ) as shown in Table 8 . These results are consistent with the hypothesis. In Montgomery County, the 50th percentile speeds were $4.0 \mathrm{~km} / \mathrm{h}(2.5 \mathrm{mi} / \mathrm{h})$ lower at the treatment site than at the corresponding control site, but the increase was not statistically significant at the 0.10 level 
(Table 8).

Table 8. Comparison of Vehicle Speeds at the Treatment and Control Sites.

\begin{tabular}{|c|c|c|c|}
\hline $\begin{array}{c}\text { CITY AND } \\
\text { TREATMENT }\end{array}$ & $\begin{array}{c}\text { 50TH } \\
\text { PERCENTILE } \\
\text { SPEED } \\
\text { TREATMENT } \\
\text { SITE }\end{array}$ & $\begin{array}{c}\text { 50TH } \\
\text { PERCENTILE } \\
\text { SPEED } \\
\text { CONTROL SITE }\end{array}$ & $\begin{array}{l}\text { DIFFERENCE IN } \\
\text { SPEEDS }\end{array}$ \\
\hline $\begin{array}{l}\text { Durham, NC - Research } \\
\text { Drive } \\
\text { Raised crosswalk }\end{array}$ & $\begin{array}{l}33.3 \mathrm{~km} / \mathrm{h} \\
(20.7 \mathrm{mi} / \mathrm{h})\end{array}$ & $\begin{array}{l}39.8 \mathrm{~km} / \mathrm{h} \\
(24.7 \mathrm{mi} / \mathrm{h})\end{array}$ & $\begin{array}{l}6.5 \mathrm{~km} / \mathrm{h}(4.0 \mathrm{mi} / \mathrm{h}) \\
\text { lower at treatment site } \\
\text { SIGNIFICANT }^{1}\end{array}$ \\
\hline $\begin{array}{l}\text { Durham, NC - Towerview } \\
\text { Drive } \\
\text { Raised crosswalk \& } \\
\text { overhead flasher }\end{array}$ & $\begin{array}{l}18.5 \mathrm{~km} / \mathrm{h} \\
(11.5 \mathrm{mi} / \mathrm{h})\end{array}$ & $\begin{array}{l}38.4 \mathrm{~km} / \mathrm{h} \\
(23.9 \mathrm{mi} / \mathrm{h})\end{array}$ & $\begin{array}{l}19.3 \mathrm{~km} / \mathrm{h}(12.4 \mathrm{mi} / \mathrm{h}) \\
\text { lower at treatment site } \\
\text { SIGNIFICANT }\end{array}$ \\
\hline $\begin{array}{l}\text { Montgomery County, } \mathrm{MD}^{2} \\
\text { Raised Crosswalk }\end{array}$ & $\begin{array}{l}34.6 \mathrm{~km} / \mathrm{h} \\
(21.5 \mathrm{mi} / \mathrm{h})\end{array}$ & $\begin{array}{l}38.6 \mathrm{~km} / \mathrm{h} \\
(24.0 \mathrm{mi} / \mathrm{h})\end{array}$ & $\begin{array}{l}4.0 \mathrm{~km} / \mathrm{h}(2.5 \mathrm{mi} / \mathrm{h}) \\
\text { lower at treatment site } \\
\text { NOT SIGNIFICANT }\end{array}$ \\
\hline
\end{tabular}

Significant at the 0.05 level or better, using a two-tailed test.

2 Vehicle speeds in Montgomery County were measured only when the staged pedestrian was present

\section{Pedestrians for Whom Motorists Stopped}

Raised crosswalks elevate pedestrians so that they are easier for motorists to see. Thus, it was thought that motorists would stop for a higher percentage of pedestrians in raised crosswalks than in standard crosswalks.

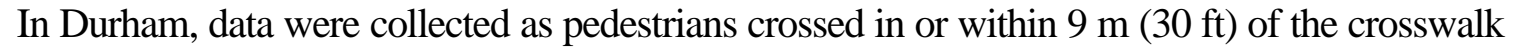
while a motorist was approaching. The researcher observed pedestrians who crossed and recorded whether motorists yielded.

Because of low pedestrian activity in Montgomery County, it was necessary to stage pedestrian crossings, using a two-person data collection team. A female researcher moved into a staging position when a vehicle was 92 to $183 \mathrm{~m}$ (300 to $600 \mathrm{ft}$ ) upstream from the crosswalk. In the staging position, the researcher stood at or near the curb and looked at oncoming traffic as if she were getting ready to cross the roadway. The second member of the team observed whether motorists slowed down when they saw the staged pedestrian, and whether they stopped to allow the staged pedestrian to cross.

Motorists stopped for a much higher percentage of pedestrians at the raised crosswalk with an 
overhead flasher in Durham than at the corresponding control site (Table 9). Results for the raised crosswalk on Research Drive in Durham are not listed in Table 9 because almost no pedestrians at the corresponding control site crossed while vehicles were approaching. The difference between the treatment and control sites in Montgomery County were not statistically significant, not even at the 0.10 level.

Table 9. Pedestrians for Whom Motorists Stopped to Let Them Cross.

\begin{tabular}{|c|c|c|c|}
\hline SITE AND TREATMENT & $\begin{array}{c}\text { TREATMENT } \\
\text { SITE }\end{array}$ & $\begin{array}{c}\text { CONTROL } \\
\text { SITE }\end{array}$ & $\begin{array}{c}\text { SIGNIFICANC } \\
\text { E }\end{array}$ \\
\hline $\begin{array}{l}\text { Durham, NC - Towerview } \\
\text { Dr } \\
\text { Raised crosswalk and } \\
\text { overhead flasher }\end{array}$ & $79.2 \%(159)^{*}$ & $31.4 \% \quad(35)$ & $\mathrm{T}(0.000)$ \\
\hline $\begin{array}{l}\text { Montgomery County, MD } \\
\text { Raised crosswalk }\end{array}$ & $1.2 \% \quad(169)$ & $1.0 \% \quad(198)$ & $\mathrm{N}$ \\
\hline
\end{tabular}

NOTE: Staged pedestrians were used in Montgomery County.

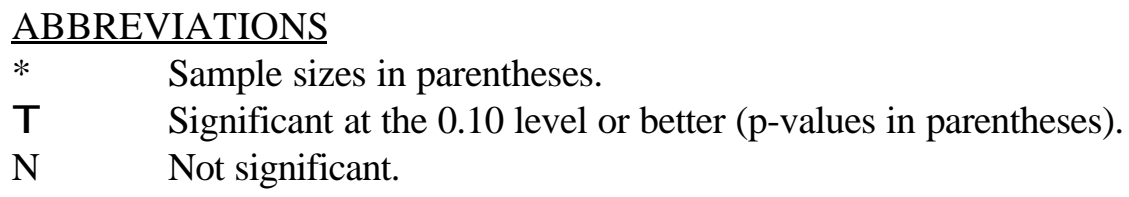

\section{RAISED INTERSECTIONS}

Before and after data were collected at one raised intersection in Cambridge, Massachusetts (Berkshire Street and Marcella Street) (Figure 8). This intersection is one block north of Marney Street, where a bulbout was installed (see above). It is in a residential area. 


\section{Pedestrians for Whom Motorists Yielded}

By constricting the roadway or creating vertical displacement, raised intersections are intended to slow vehicles down and increase the likelihood that motorists will see pedestrians sooner than they would otherwise. It was thought that raised intersections would increase the number of pedestrians for whom motorists yielded. However, because both traffic and pedestrian volumes were low, it was not possible to determine what effect, if any, the raised intersection had on this MOE.

\section{Pedestrians Who Crossed in the Crosswalk}

All of the traffic calming locations that were evaluated already had marked crosswalks in the before period. It was thought that the raised intersection would motivate pedestrians to cross in the crosswalk (who otherwise might not have done so), so that they can benefit from having a delineated crossing zone.

The chi-square statistic was used to compare the percentages of pedestrians who crossed in the crosswalk in the before and after periods. In the before period, 11.5 percent of pedestrians $(\mathrm{N}=$ 104) crossed in the crosswalk. This percentage increased to 38.3 percent $(\mathrm{N}=47)$ in the after

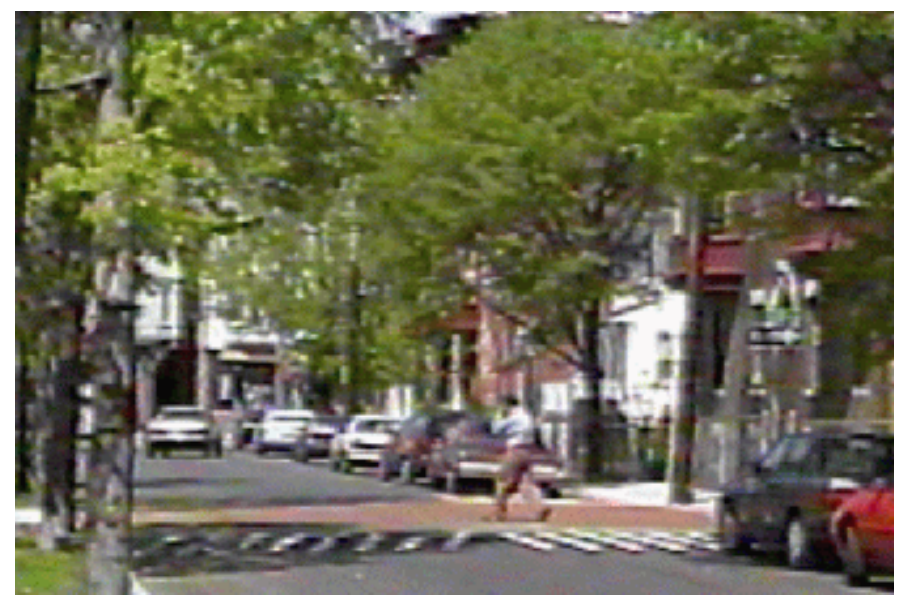

Figure 8. Raised intersection, Berkshire Street and Marcella Street, Cambridge, Massachusetts.

period. Thus, the raised intersection in Cambridge had statistically significant effects ( $\mathrm{p}$-value $=$ 0.001). In other words, more pedestrians crossed in the crosswalk in the after period than in the before period. 


\section{Average Pedestrian Wait Time}

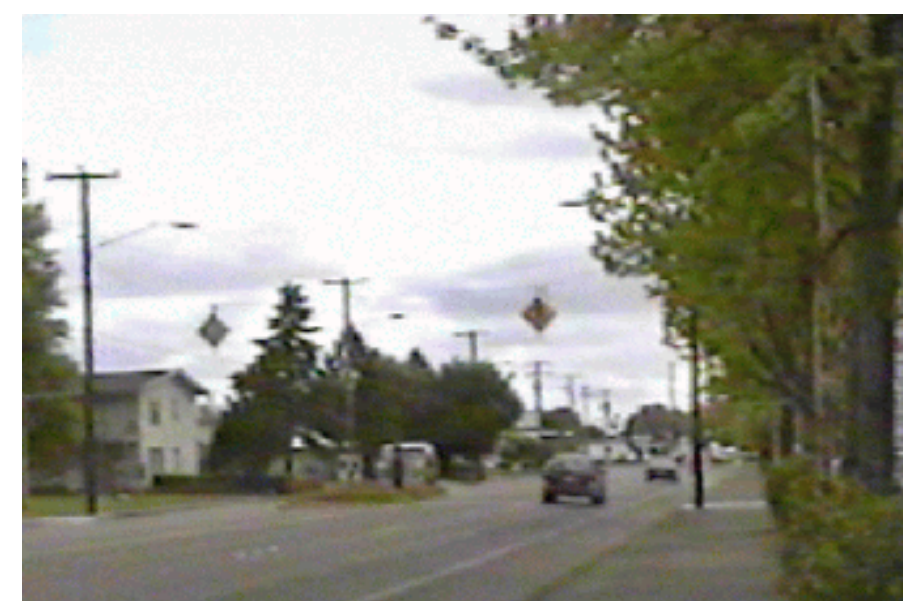

Figure 9. Refuge island, Circle Boulevard, Corvallis, Oregon.

The average wait time was $0.04 \mathrm{~s}(\mathrm{~N}=104)$ in the before period and $0.00 \mathrm{~s}(\mathrm{~N}=47)$ in the after period. According to the $t$ test for difference in means, this change was not statistically significant. Because traffic volumes were very light, the majority of pedestrians crossed without having to wait for a gap in traffic, so the average wait times were very short.

\section{REFUGE ISLANDS}

Five refuge islands in two cities were evaluated using a before and after study approach.

1. Circle Boulevard, Corvallis, OR

2. E Street at $23^{\text {rd }}$ Street, east leg, Sacramento, CA

3. E Street at $23^{\text {rd }}$ Street, west leg, Sacramento, CA

4. F Street at $23^{\text {rd }}$ Street, east leg, Sacramento, CA

5. F Street at $23^{\text {rd }}$ Street, west leg, Sacramento, CA

Circle Boulevard is an urban arterial in Corvallis, Oregon (Figure 9). It has two lanes in each direction and a center left-turn lane, for a total of five lanes. A mid-block marked cross- walk and a refuge island were installed. The refuge island has a cut-through for the crosswalk. The crosswalk connects an apartment complex to the north with a shopping center to the south.

The refuge islands in Sacramento were installed along with zebra crosswalks. The two intersections are in the Midtown neighborhood, in a predominantly residential area. Both $\mathrm{E}$ and $\mathrm{F}$ 
Streets run east-west, and are two-way, two-lane, with parking on both sides. Traffic and pedestrian activity appeared to be higher on F Street, owing to the presence of a supermarket on the northwest corner.

\section{Pedestrians for Whom Motorists Yielded}

By constricting the roadway, refuge islands are intended to slow vehicles down and increase the likelihood that motorists will see pedestrians sooner than they would otherwise. Therefore, it was hypothesized that refuge islands would increase the number of pedestrians for whom motorists yielded. In other words, more pedestrians would have the benefit of motorists yielding to them.

The chi-square statistic was used to compare the percentages of pedestrians for whom motorists yielded in the before and after periods. None of the treatments had a statistically significant effect on the percentage of pedestrians for whom motorists yielded, not even at the 0.10 level (Table 10). In the after period, motorists yielded to about two-thirds of the pedestrians in the best case, and to only 8 percent in the worst case. The refuge island in Corvallis had small sample sizes.

Table 10. Percentage of Pedestrians for Whom Motorists Yielded, Before and After Treatment.

\begin{tabular}{|l|l|l|l|c|}
\hline \multicolumn{1}{|c|}{ LOCATION } & TREATMENT & BEFORE & AFTER & $\begin{array}{c}\text { SIGNIFICANC } \\
\text { E }\end{array}$ \\
\hline Corvallis, OR & $\begin{array}{c}\text { Refuge island } \\
\text { and pavement } \\
\text { markings }\end{array}$ & $5.7 \%(35)^{*}$ & $7.5 \% \quad(53)$ & $\mathrm{S}$ \\
\hline Sacramento, CA & $\begin{array}{c}\text { Refuge islands } \\
\text { with zebra } \\
\text { crosswalks } \\
4 \text { locations }\end{array}$ & $32.6 \% \quad(46)$ & $42.1 \% \quad(38)$ & $\mathrm{N}$ \\
\hline
\end{tabular}

ABBREVIATIONS

* Sample sizes in parentheses.

$\mathrm{N}$ Not significant.

S Small sample size.

\section{Where Do Pedestrians Cross?}

All of the traffic calming locations that were evaluated already had marked crosswalks in the before period. It was thought that refuge islands would motivate pedestrians to cross in the crosswalk, so that they can benefit from having a place of refuge in the middle of traffic (Figure 10). 
The chi-square statistic was used to compare the percentages of pedestrians who crossed in the crosswalk in the before and after periods. As Table 11 shows, the refuge islands in Sacramento had statistically significant effects, i.e., more pedestrians crossed in the crosswalk in the after period than in the before period. The effects of the refuge island in Corvallis were in the desired direction but were not statistically significant, not even at the 0.10 level.

Table 11. Percentage of Pedestrians Who Crossed in the Crosswalk, Before and After Treatment.

\begin{tabular}{|l|l|l|ll|c|}
\hline \multicolumn{1}{|c|}{ LOCATION } & TREATMENT & BEFORE & \multicolumn{2}{|c|}{ AFTER } & $\begin{array}{c}\text { SIGNIFICANC } \\
\text { E }\end{array}$ \\
\hline Corvallis, OR & $\begin{array}{c}\text { Refuge island } \\
\text { and pavement } \\
\text { markings }\end{array}$ & $51.9 \% \quad(79)^{*}$ & $78.0 \% \quad(113)$ & $\mathrm{N}$ \\
\hline Sacramento, CA & $\begin{array}{c}\text { Refuge islands } \\
\text { with zebra } \\
\text { crosswalks } \\
4 \text { locations }\end{array}$ & $61.5 \% \quad(314)$ & $71.9 \% \quad(224)$ & T (0.012) \\
\hline
\end{tabular}

ABBREVIATIONS

* Sample sizes in parentheses.

$\mathrm{T} \quad$ Significant at the 0.10 level or better (p-values in parentheses).

$\mathrm{N}$ Not significant.

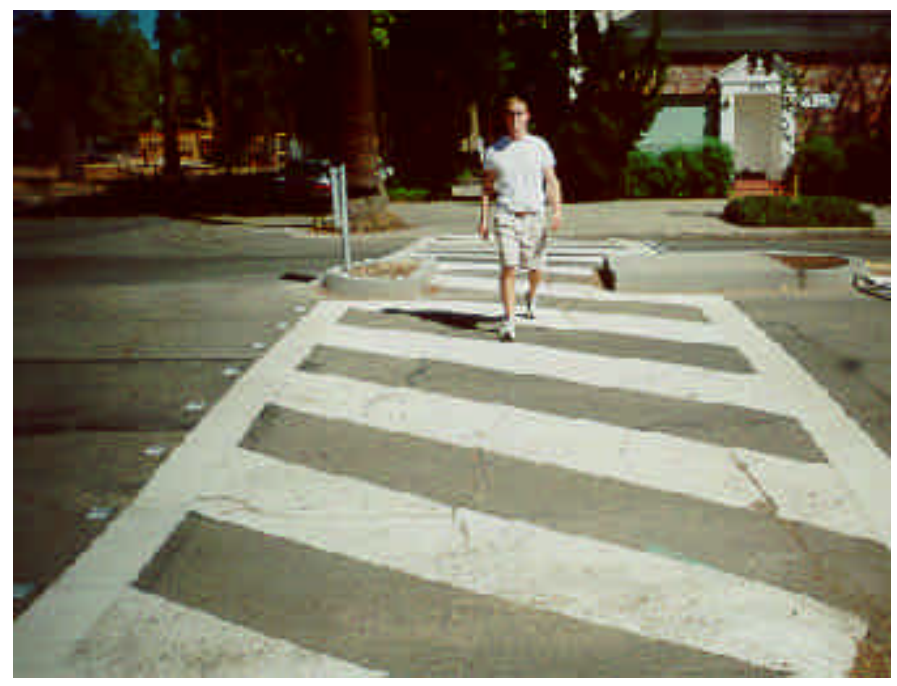

Figure 10. Pedestrian in crosswalk with refuge island, Sacramento, California. 


\section{Average Pedestrian Wait Time}

Because refuge islands allow pedestrians to cross one direction of traffic at a time, pedestrians may choose a shorter gap than if they had to cross both directions of traffic. Therefore, it was expected that refuge islands would shorten the time that pedestrians must wait to cross the street. In this study, wait times were recorded for all pedestrians who crossed the street, regardless of whether motor vehicles were approaching.

The $t$ test for difference in means was used to compare average pedestrian wait times in the before and after periods (Table 12). Neither the refuge islands in Corvallis nor those in Sacramento had a significant effect on pedestrian wait time, not even at the 0.10 level.

Table 12. Average Pedestrian Wait Time, Before and After Treatment.

\begin{tabular}{|l|l|c|c|c|}
\hline \multicolumn{1}{|c|}{ LOCATION } & TREATMENT & BEFORE & AFTER & SIGNIFICANCE \\
\hline Corvallis, OR & $\begin{array}{c}\text { Refuge island and } \\
\text { pavement } \\
\text { markings }\end{array}$ & $\begin{array}{c}8.59 \mathrm{~s} \\
(75)^{*}\end{array}$ & $\begin{array}{c}6.68 \mathrm{~s} \\
(110)\end{array}$ & $\mathrm{N}$ \\
\hline Sacramento, CA & $\begin{array}{l}\text { Refuge islands and } \\
\text { zebra crosswalks } \\
4 \text { locations }\end{array}$ & $\begin{array}{c}1.59 \mathrm{~s} \\
(289)\end{array}$ & $\begin{array}{c}1.54 \mathrm{~s} \\
(214)\end{array}$ & $\mathrm{N}$ \\
\hline
\end{tabular}

ABBREVIATIONS

$\mathrm{N}$ Not significant.

* Sample sizes in parentheses.

\section{DISCUSSION}

Overall vehicle speeds for the raised crosswalks in Durham were lower compared with their matching control sites. This suggests that the raised crosswalks in Durham were effective in reducing vehicle speeds. Vehicle speeds in Montgomery County were measured only in the presence of staged pedestrians. The speeds at the raised crosswalk and control sites in Montgomery County were about the same, an indication that the raised crosswalk had no effect on vehicle speeds.

Evaluations were conducted to determine if motorists would be more likely to stop for unstaged pedestrian crossings than crossings staged from the data collection team. Table 3 suggests that motorists are more likely to yield to unstaged pedestrians than to staged pedestrians — as many as 70 
percent of unstaged pedestrians but less than 5 percent of staged pedestrians. No observations of both unstaged pedestrians and staged pedestrians in the same city were made, because pedestrian crossings were staged only when pedestrian activity was low. As a result, the reason why motorists yielded more often to unstaged pedestrians is possibly a result of city-by-city or site-by-site differences. It may also be that, to some motorists, the staged pedestrian did not appear to want to cross the roadway.

Table 13 summarizes the effect of traffic calming devices by site and MOE. For example, the bulbouts in Seattle did not have an effect on wait times or whether pedestrians used the crosswalk. The effect on the number of pedestrians for whom motorists yielded was not determined because of small sample sizes. Vehicle speeds were not measured at those bulbouts.

Average pedestrian wait times were usually under $2 \mathrm{~s}$ (Tables 3 and 12). The short wait times indicate that most pedestrians started crossing as soon as they reached the curb, or within a few seconds thereafter. Motor vehicle traffic volumes were usually not very high, so adequate gaps for pedestrians to cross the roadway came frequently, without a long wait. The

Table 13. Summary of Traffic Calming Devices by Site and MOE.

\begin{tabular}{|l|c|c|c|c|}
\hline \multicolumn{1}{|c|}{$\begin{array}{c}\text { TREATMENT } \\
\text { AND CITY }\end{array}$} & $\begin{array}{c}\text { VEHICLE } \\
\text { SPEED }\end{array}$ & $\begin{array}{c}\text { PEDESTRIANS } \\
\text { FOR WHOM } \\
\text { MOTORISTS } \\
\text { YIELDED }\end{array}$ & $\begin{array}{c}\text { PEDESTRIAN } \\
\text { WAIT TIME }\end{array}$ & $\begin{array}{c}\text { No Change } \\
\text { CROSSWALK }\end{array}$ \\
\hline $\begin{array}{l}\text { BULBOUTS (2 locations) } \\
\text { Cambridge, MA }\end{array}$ & N/A & $*$ & Whange \\
\hline $\begin{array}{l}\text { BULBOUTS (2 locations) } \\
\text { Seattle, WA }\end{array}$ & N/A & No Change & Worse & Norse \\
\hline $\begin{array}{l}\text { BULBOUTS (2 locations) } \\
\text { Greensboro, NC }\end{array}$ & Improve & No Change & N/A & N/A \\
\hline $\begin{array}{l}\text { BULBOUTS (2 locations) } \\
\text { Richmond, VA }\end{array}$ & Worse & No Change & N/A & N/A \\
\hline $\begin{array}{l}\text { RAISED CROSSWALK } \\
\text { Durham, NC }\end{array}$ & Improve & $*$ & N/A & N/A \\
\hline $\begin{array}{l}\text { RAISED CROSSWALK \& } \\
\text { OVERHEAD FLASHER } \\
\text { Durham, NC }\end{array}$ & Improve & Improve & N/A & N/A \\
\hline $\begin{array}{l}\text { RAISED CROSSWALK } \\
\text { Montgomery County, MD }\end{array}$ & No Change & No Change & N/A & N/A \\
\hline
\end{tabular}




\begin{tabular}{|l|c|c|c|c|}
\hline $\begin{array}{l}\text { RAISED INTERSECTION } \\
\text { Cambridge, MA }\end{array}$ & N/A & N/A & No Change & Improve \\
\hline $\begin{array}{l}\text { REFUGE ISLANDS \& } \\
\begin{array}{l}\text { ZEBRA CROSSWALKS } \\
(4 \text { locations })\end{array}\end{array}$ & N/A & No Change & No Change & Improve \\
Sacramento, CA & & & & \\
\hline $\begin{array}{l}\text { REFUGE ISLAND \& } \\
\text { PAVEMENT MARKINGS } \\
\text { Corvallis, OR }\end{array}$ & N/A & $*$ & No Change & No Change \\
\hline
\end{tabular}

ABBREVIATIONS

N/A Data were not collected for this MOE.

Improve Significant improvement at 0.10 level.

Worse Conditions significantly worse at 0.10 level.

* $\quad$ Small sample size.

wait times did not change much between the before and after periods. However, the wait times in the before period were close to zero and could not get much shorter, nor did they get much longer. In fact, the change in wait times at four of the sites turned out to be not statistically significant. It is likely that wait times will fluctuate from one day to the next in response to vehicle and pedestrian volumes, and vehicle speeds. The significant effect in the wrong direction at the other two sites may be partly the result of these fluctuations in pedestrian and motor vehicle volumes.

\section{CONCLUSIONS}

These findings suggest that bulbouts and raised crosswalks can reduce motor vehicle speeds. The combination of a raised crosswalk with an overhead flasher was most effective in encouraging motorists to yield to pedestrians. It is not known what effect was from the flasher and what portion can be attributed to the raised crosswalk. Raised intersections and refuge islands are likely to direct more pedestrians to cross within the crosswalk.

At most sites, however, these traffic calming devices did not have significant effects on pedestrians. In fact, the bulbouts in Seattle were associated with increased wait times and a lower percentage of those who crossed in the crosswalk, both undesirable effects from a pedestrian standpoint. These results may be due to a fluctuation in traffic conditions at the site.

The reader is cautioned that traffic calming devices are not a panacea guaranteed to improve conditions for pedestrians. These devices by themselves cannot ensure that motorists will slow down 
and yield to pedestrians, nor that pedestrians will cross in the crosswalk. Moreover, traffic calming devices have their disadvantages. For example, these treatments can hinder activities such as street cleaning and snow plowing, may impede emergency vehicle access, and may affect drainage. The noise of vehicles going over speed humps, raised crosswalks, and raised intersections may disturb nearby residents.

The ultimate evaluation of traffic calming devices would consist of a safety-based analysis using 3 or more years of collision records, adding more study sites, and including other devices (such as traffic circles) that were not examined in this study. Such an evaluation was beyond the scope of this study, but should eventually be conducted.

\section{ACKNOWLEDGMENTS}

This study was conducted as part of a research project funded by the Federal Highway Administration, under contract number DTFH61-92-C-00138. Carol Tan Esse (Federal Highway Administration) served as the Contracting Officer's Technical Representative and Charles Zegeer (University of North Carolina Highway Safety Research Center) was the Principal Investigator. The authors gratefully acknowledge the many individuals, too numerous to list here, who assisted with data collection. Eric Rodgman and J. Richard Stewart (both from University of North Carolina Highway Safety Research Center) provided computer and statistical expertise, respectively.

\section{REFERENCES}

1. ITE Technical Council Speed Humps Task Force. Guidelines for the Design and Application of Speed Humps, Institute of Transportation Engineers, Washington, DC, March 1993.

2. Marcel Klik and Ardeshir Faghri. "A Comparative Evaluation of Speed Humps and Deviations," Transportation Quarterly, Vol. 47, No. 3, July 1993, pp. 457-469.

3. Andrew Clarke and M.J. Dornfeld. Traffic Calming, Auto-Restricted Zones and Other Traffic Management Techniques - Their Effects on Bicycling and Pedestrians, Case Study No. 19, National Bicycling and Walking Study, Publication No. FHWA-PD-93-028, Federal Highway Administration, Washington, DC, January 1994.

4. David A. Loughery and Marcy Katzman. Montgomery County, Maryland Speed Hump Program Evaluation Report. Prepared for presentation to the Montgomery County Council, January 1998. 
5. C. Edward Walter. "Suburban Residential Traffic Calming, ITE Journal, Vol. 65, No. 9, September 1995, pp. 44-48.

6. Edward Cline. "Design of Speed Humps...Or 'The Kinder, Gentler Speed Hump."' Presented at the 45th California Symposium on Transportation Issues, May 12-14, 1993.

7. P.E. McDonald and J.R. Jarvis. The Use of Road Humps on Residential Streets in the Shire of Corio, ARRB Internal Report, AIR 335-2, Australian Road Research Board, 1981.

8. E. Richardson and J.R. Jarvis. The Use of Road Humps on Residential Streets in the City of Stirling, Western Australia. ARRB Internal Report, AIR 335-3, Australian Road Research Board, 1981.

9. Ludmilla Hawley, Colin Henson, Andrew Hulse, and Ray Brindle. Towards Traffic Calming: A Practitioners' Manual of Implemented Local Area Traffic Management and Blackspot Devices, Publication No. CR 126, Federal Office of Road Safety, Canberra, Australian Capital Territory, Australia, August 1992.

10. A. Macbeth. "Balliol Street" Traffic Calming 1995, proceedings from 21 papers, Ontario Traffic Conference, November 1995.

11. Michael Replogle. Bicycle and Pedestrian Policies and Programs in Asia, Australia, and New Zealand. Case Study 17, National Bicycling and Walking Study. Report No. FHWAPD-93-016. Federal Highway Administration, Washington, DC, April 1992. 